\begin{tabular}{|l|l|l||}
\hline \multicolumn{2}{|c|}{ PublisherInfo } \\
\hline \hline PublisherName & $:$ & BioMed Central \\
\hline \hline PublisherLocation & $:$ & London \\
\hline \hline PublisherImprintName & $:$ & BioMed Central \\
\hline \hline
\end{tabular}

\title{
NIH names computational boss
}

\begin{tabular}{|l|l|l||}
\hline \multicolumn{2}{|c|}{ ArticleInfo } \\
\hline \hline ArticleID & $:$ & 4783 \\
\hline \hline ArticleDOI & $:$ & $10.1186 /$ gb-spotlight-20030605-01 \\
\hline \hline ArticleCitationID & $:$ & spotlight-20030605-01 \\
\hline \hline ArticleSequenceNumber & $:$ & 135 \\
\hline \hline ArticleCategory & $:$ & Research news \\
\hline ArticleFirstPage & $:$ & 1 \\
\hline \hline ArticleLastPage & $:$ & 3 \\
\hline \hline & & RegistrationDate : 2003-6-5 \\
\hline ArticleHistory & $:$ & OnlineDate \\
\hline \hline ArticleCopyright & $:$ & BioMed Central Ltd2003-6-5 \\
\hline \hline ArticleGrants & $:$ & \\
\hline \hline ArticleContext & $:$ & 130594411 \\
\hline \hline
\end{tabular}


Willie Schatz

Email:willie@schatzgroup.com

After a 2-year process, the National Institute of General Medical Sciences (NIGMS) has named University of Illinois at Urbana-Champaign Professor Eric Jakobsson the first director of its Center for Bioinformatics and Computational Biology (CBCB).

Jakobsson replaces James Cassatt, director of the National Institutes of Health's (NIH) NIGMS Division of Cell Biology and Biophysics, who had served as CBCB's acting director since the center was established in 2001. The new director holds dual professorships in the Department of Molecular and Integrative Physiology and in the programs of biophysics, neuroscience, and bioengineering at UrbanaChampaign. He will continue to lead research groups at the university, but will not have teaching responsibilities.

"It's very good news that NIH finally got someone to move forward with BISTI [the Biomedical Information Science and Technology Initiative]," said Larry Smarr, the founder of the California Institute of Telecommunications and Information Technology. "The BISTI report was presented in June 1999, and very few of the recommendations have been acted on. BISTI is the only road map for the future of NIH-sponsored research for telecommunications and information technology."

Implementing BISTI is essential to NIH's developing of the information infrastructure to support a national model for biomedical research, said Smarr, who is Jakobsson's former colleague at the National Center for Supercomputing Applications at the University of Illinois. "There hasn't been any energy or consensus at the agency to implement the BISTI recommendations," Smarr told us. "Hiring Eric shows NIH is ready to do that."

The $\mathrm{CBCB}$, which will be the centerpiece of that effort, supports research and training in areas that join biology with the computer sciences, engineering, mathematics, and physics. Such research includes computer modeling of biological networks and dynamic processes and quantitative approaches to cellular, molecular, and developmental biology.

"The most appealing part of the job is that it's undefined," Jakobsson told us. "I'm envisioning this job as putting together a nationally distributed software engineering project. Now, a program for molecular dynamics and another that simulates complex system such as a pathway in a cell aren't linked. We want to seamlessly connect them."

As Jakobsson forges ahead, he said his toughest challenge will be to get all 27 of the NIH institutes "into the harness, even though there's absolute certainty that everyone wants to get into the harness," he said. "The good news is that there is institutional momentum behind me and a willingness to work through the formal barriers to institutional independence. We will surmount them."

"This job takes someone with good people skills, and Eric's got them," Smarr said. "He's a dedicated public servant who's there to get the job done. And he won't bring his ego to it. He's a working scientist, not a bureaucrat." 
For his part, Jakobsson said he initially had some doubts about the position. "I said no when they asked me a year ago," he said. "Things weren't right for me personally. But this time I couldn't say no. It's a fantastic opportunity."

\section{References}

1. Davis A: NIGMS creates center for bioinformatics and computational biology National Institute of General Medical Sciences news release, May 14, 2001., [http://www.nigms.nih.gov/news/releases/ cbcb.html]

2. National Institute of General Medical Sciences, [http://www.nigms.nih.gov/]

3. Eric Jakobsson, [http://www.beckman.uiuc.edu/faculty/jakobsso.html]

4. Center for Bioinformatics and Computational Biology, [http://www.nigms.nih.gov/about_nigms/ cbcb.html] 